SZABÓ, Krisztina

\title{
Digital Literacy: Is Digital Reading Similar to Comic Reading? ${ }^{1}$
}

\section{Preface}

As a result of technological innovations, the way we think, the way we comprehend texts is constantly changing. The new forms of media have a strong effect on our cognitive processes. The visual elements, pictures, gifs, icons, short videos and interactive adverts significantly influence our ability to read and understand texts. This is the reason why so many researchers try to capture the essence and the effects of the recent changes of the digital environment. ${ }^{2}$

In my paper I will focus on digital reading literacy concerning the visual elements of comprehension. My main question is whether digital reading is similar to comic reading. In my essay I will argue that reading digital texts containing visual elements is a non-linear kind of reading which is indeed very much like comic reading. In order to prove my hypothesis, I will start with giving some definitions for some fundamental expressions (digital text, visual elements, non-linear reading, and comics) which I will constantly use in my work. Secondly, I will draw up the main characteristics of digital reading in accordance with the latest literature. Then I will give a short summary of the specifics of comic reading. Finally, I will make a comparison between comic reading and digital reading focusing on their similarities. In the end of my paper I will provide a prognosis for further possible research, too. My aim is to get a better understanding of digital literacy and reading process.

\section{Introduction, hypothesis}

As a starting point I have to make it clear that visual elements which appear on digital interfaces have strong effects and influence on our cognitive processes, especially on reading and text comprehension. My aim is to get a better understanding of these elementary changes.

I have two basic questions:

1. Do we read in a new kind of way, therefore we need new types of texts?

2. Do we have new types of texts; therefore we need to read in new kinds of ways?

To answer these questions, I should find a common point of printed and digital texts/printed and digital reading.

\footnotetext{
${ }^{1}$ This research progresses in the framework of the Integral Argumentation Studies (OTKA - K-109456) of the Doctoral School of Philosophy and History of Science, Budapest University of Technology and Economics.

2 Mary C. Dyson and Gary J. Kipping, "Exploring the effect of layout on reading from screen", in Roger D. Hersch, Jacques André and Heather Brown (eds.), Electronic publishing, artistic imaging, and digital typography: Seventh International Conference on Electronic Publishing: Proceedings, Berlin: Springer-Verlag, pp. 294-304; Karen Coyle, "Managing Technology: Meaning, technology, and the semantic web (2008), http://www.sciencedirect.com/science/article/pii/S0099133308000426, last accessed 25. 01. 2015); William C. Dougherty, "Managing Technology, The book is dead, long live the book!" (2011), http://www.sciencedirect.com/science/article/pii/S0099133311001959, last accessed 25. 01. 2015; Eve Bearne, Chris Clark, Annette Johnson, Penny Manford, Marilyn Mottram and Helen Wolstencroft with Rosemary Anderson and Nikki Gamble, Reading on screen. Leicester: United Kingdom Literacy Association, 2007.
} 
Reviewing the related literature about reading, text typologies and comprehension, I started to be interested in the forms of special digital texts (short messages, e-mail letters, posts, comments, and comics) because I think that their similarities and differences are particularly suitable for discovering digital reading processes. As a confirmation for this I found a promising idea by Tamás Dunai: "Reading comics [on all the digital multimedia tools mentioned above] can be compared mostly to the active user activity of the Internet." ${ }^{3}$ This idea suggested the following question: what if I carry on this analogy in a much more focused way, comparing the reading process of comics to the reading process of digital texts? I did a research on this question and finally I came up with the following hypothesis: reading digital texts containing visual elements is a non-linear kind of reading which is similar to comic reading. Henceforth my aim is to confirm this statement.

\section{Definitions: digital text, visual elements, non-linear reading, comics}

At this point it is necessary to define some expressions which I will constantly use in my essay. The importance of this definition process lies in my intention of giving an unequivocal paper about my thesis. The expressions in question are the following: digital texts, visual elements, non-linear reading and comics.

The first basic notion is digital text. I take digital text to be a text which we can read on the display of our e-book or other technological devices like PCs, notebooks, tablets, cell phones and smart phones. They also include e-bills and every text on websites (Figure 1). In plain words: digital texts are texts stored as strings of characters on a technological device. ${ }^{4}$
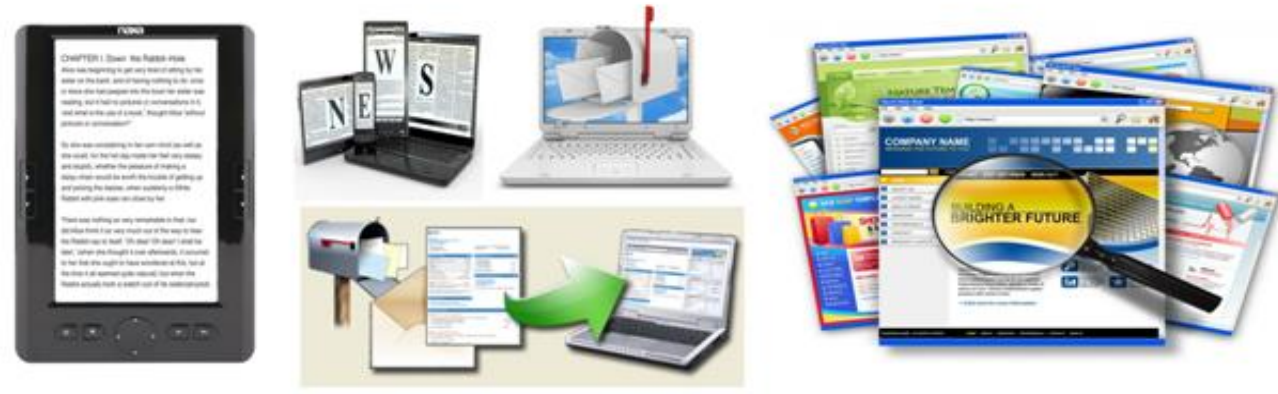

Figure 1: Examples of digital texts

Digital texts are hypertexts ${ }^{5}$; in other words, networks of web links which spread all over the online space. ${ }^{6}$ They are also hybrid texts, ${ }^{7}$ which means they are a kind of design product

\footnotetext{
${ }^{3}$ Tamás Dunai, “Képregény Magyarországon” [Comics in Hungary], Médiakutató, Spring 2007, http://www.mediakutato.hu/cikk/2007 01 tavasz/02 kepregeny magyarorszagon, last accessed 14. 01.2015.

${ }^{4}$ Razia Pullen, "Technology Tools for Reading. Technology Tips for Differentiated Instruction", JRF/2006, p. 2, http://www.broward.k12.fl.us/studentsupport/ese/PDF/Whatisdigital.pdf, last accessed 14. 01. 2015.

${ }^{5}$ Barry W. Cull, "Reading revolutions: Online digital text and implications for reading in academe", First Monday, vol. 16, no. 6, June 6, 2011, http://firstmonday.org/ojs/index.php/fm/article/view/3340/2985, last accessed 14. 01. 2015; Jay Bolter, Writing space: The computer, hypertext, and the history of writing, Hillsdale, NJ: Lawrence Erlbaum, 1991; Jay Bolter, Writing space: The computer, hypertext, and the remediation of print, second edition, Mahwah, NJ: Lawrence Erlbaum, 2001.

${ }^{6}$ Barry W. Cull, "Reading revolutions: Online digital text and implications for reading in academe", First Monday, vol. 16, no. 6, June 6, 2011, http://firstmonday.org/ojs/index.php/fm/article/view/3340/2985, last accessed 14. 01. 2015; Jay Bolter, Writing space: The computer, hypertext, and the history of writing, Hillsdale, NJ: Lawrence Erlbaum, 1991; Jay Bolter, Writing space: The computer, hypertext, and the remediation of print, second edition, Mahwah, NJ: Lawrence Erlbaum, 2001.
} 
for the readers. Reading a digital text is a constitutive, constructive and transforming process when syntax and semantics, such as cohesion and coherence function in a special form. ${ }^{8}$ Cohesion means the syntax at the macro level of expressions, the predicative structure and the connection of sentences. At micro level it refers to the relationship of single phrases and grammatical units. Coherence is the meaning of the text, not just the possible interpretations of the expressions but also the meaning and knowledge in context. ${ }^{9}$ Because of these features it is required to reconstruct the definitions of writing and reading that is the main topic of numerous current researches. ${ }^{10}$

The second important expression is visual element. I consider visual elements to be pictures, graphics, and any kind of design elements of a website, word clouds and gifs. The interactive advertisements and the graphical elements of a Prezi or a Power Point presentation are also visual elements, such as the statistics vector icons, the smart art pictures, the opening pictures of a notebook or a smartphone with all their colourful and dynamic icons. In my view even an embedded YouTube video counts as a visual element (Figures 2 and 3 ).
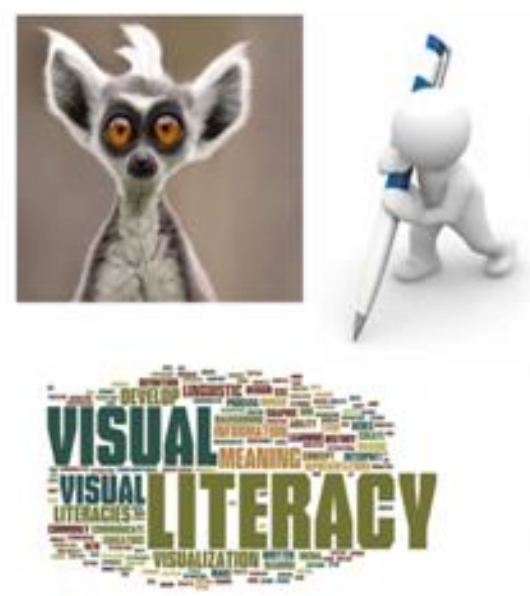
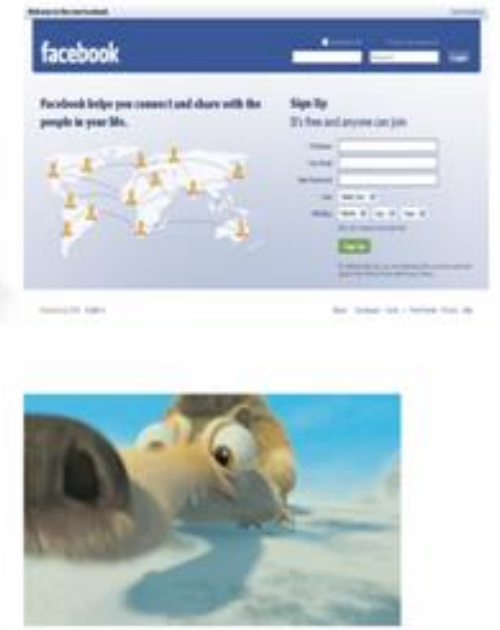

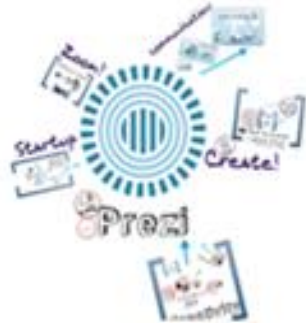

3 Weight Loss Mistakes

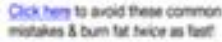
$(6)$

Figure 2: Examples of visual elements

However, here it is very important to mention that digital literacy surveys such as PISAtests (the regular international surveys of the Program for International Student Assessment) examine only those visual elements which are explicitly and essentially connected to a

\footnotetext{
7Maureen Walsh, "Multimodal literacy: What does it mean for classroom practice?", Australian Journal of Language Literacy, vol. 33, no. 3 (October 2010), p. 224.

${ }^{8}$ Barry W. Cull, "Reading revolutions: Online digital text and implications for reading in academe", First Monday, vol. 16, no. 6, June 6, 2011, http://firstmonday.org/ojs/index.php/fm/article/view/3340/2985, last accessed 14. 01. 2015; David L. Ulin, "The lost art of reading", Los Angeles Times, August 9, 2009, http://articles.latimes.com/2009/aug/09/entertainment/ca-reading9, last accessed 14. 01. 2015.

${ }^{9}$ Barry W. Cull, "Reading revolutions: Online digital text and implications for reading in academe", First Monday, vol. 16, no. 6, June 6, 2011, http://firstmonday.org/ojs/index.php/fm/article/view/3340/2985, last accessed 14. 01. 2015; David L. Ulin, "The lost art of reading", Los Angeles Times, August 9, 2009, http://articles.latimes.com/2009/aug/09/entertainment/ca-reading9, last accessed 14. 01. 2015. ${ }^{10}$ Maureen Walsh, "Multimodal literacy: What does it mean for classroom practice?", Australian Journal of Language Literacy, vol. 33, no. 3 (October 2010), p. 224.
} 
written text. ${ }^{11}$ But in my view, visual elements are all the visual contents which appear in the context of a text as additional, explicative or illustrative elements.

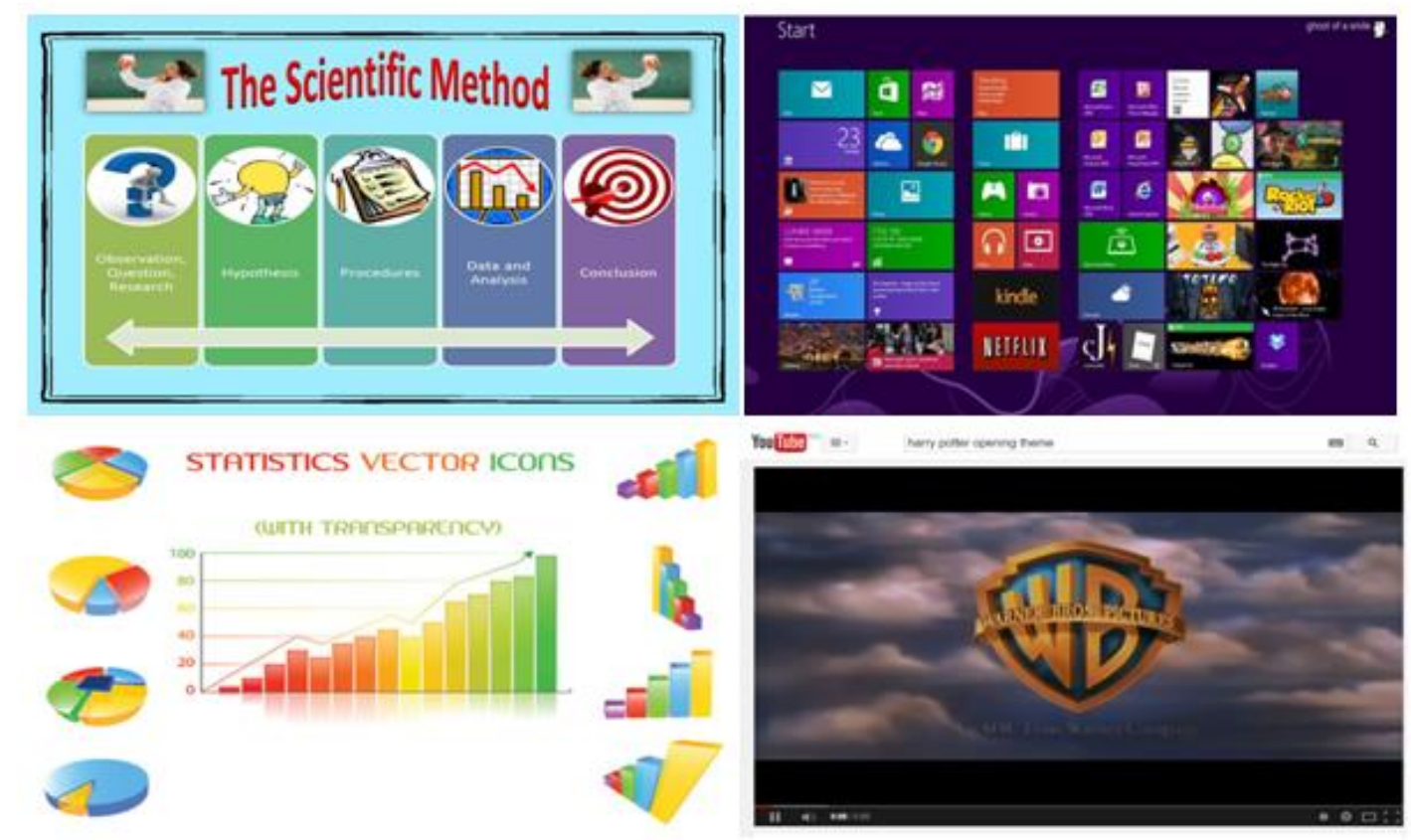

Figure 3: Examples of visual elements

Now it is time to define what does non-linear reading mean, which is the most important characteristic relevant to digital texts. In the history of reading, the current usage of digital devices represents the biggest change at the level of media. ${ }^{12}$ This is true particularly for the ramified nature of the text. This basic difference compared to the printed text implies the greatest difficulty in reading and understanding digital texts.

Non-linear reading is a special kind of reading. It is fragmental, scanning, superficial, bouncing, simultaneous, information sorting, fast and pictorial. It concentrates on the individual elements and also on the users. Non-linear reading primarily facilitates rapid information searching rather than in-depth reading. This new reading strategy was created as a result of the hypertext where intertextuality enters another dimension. ${ }^{13}$

\section{A special way of reading: comics}

\footnotetext{
${ }^{11}$ Ildikó Balázs et al., A PISA2009 tartalmi és technikai jellemzői [Material and technical features of PISA2009], Budapest: Oktatási Hivatal, 2010, https://www.oktatas.hu/pub bin/dload/kozoktatas/nemzetkozi meresek/pisa/A PISA2009 tartalmi es techn ikai jellemzoi.pdf, last accessed 25. 01. 2015.

12 Terje Hillesund, "Digital reading spaces: How expert readers handle books, the Web and electronic paper", First Monday, vol. 15, no. 5 (April 5, 2010), http://firstmonday.org/article/view/2762/2504, last accessed 14. 01. 2015.

${ }^{13}$ Krisztina Szabó, “A digitális szövegértés felmérése - A 2009-es PISA-teszt definíciós problémái” [Digital Literacy Survey - The definitional problems of the 2009 PISA test], to appear in 2015.
} 
Finally I will define what I call comic. Comic is a part of literature and fine art, too (Figure 4). But - what is more important - comic is a medium ${ }^{14}$ which we have to read in a special way. I said medium because none of its narrative systems is merely additional. We read it in a special way because we have to discover the narrative connections among pictures. ${ }^{15}$
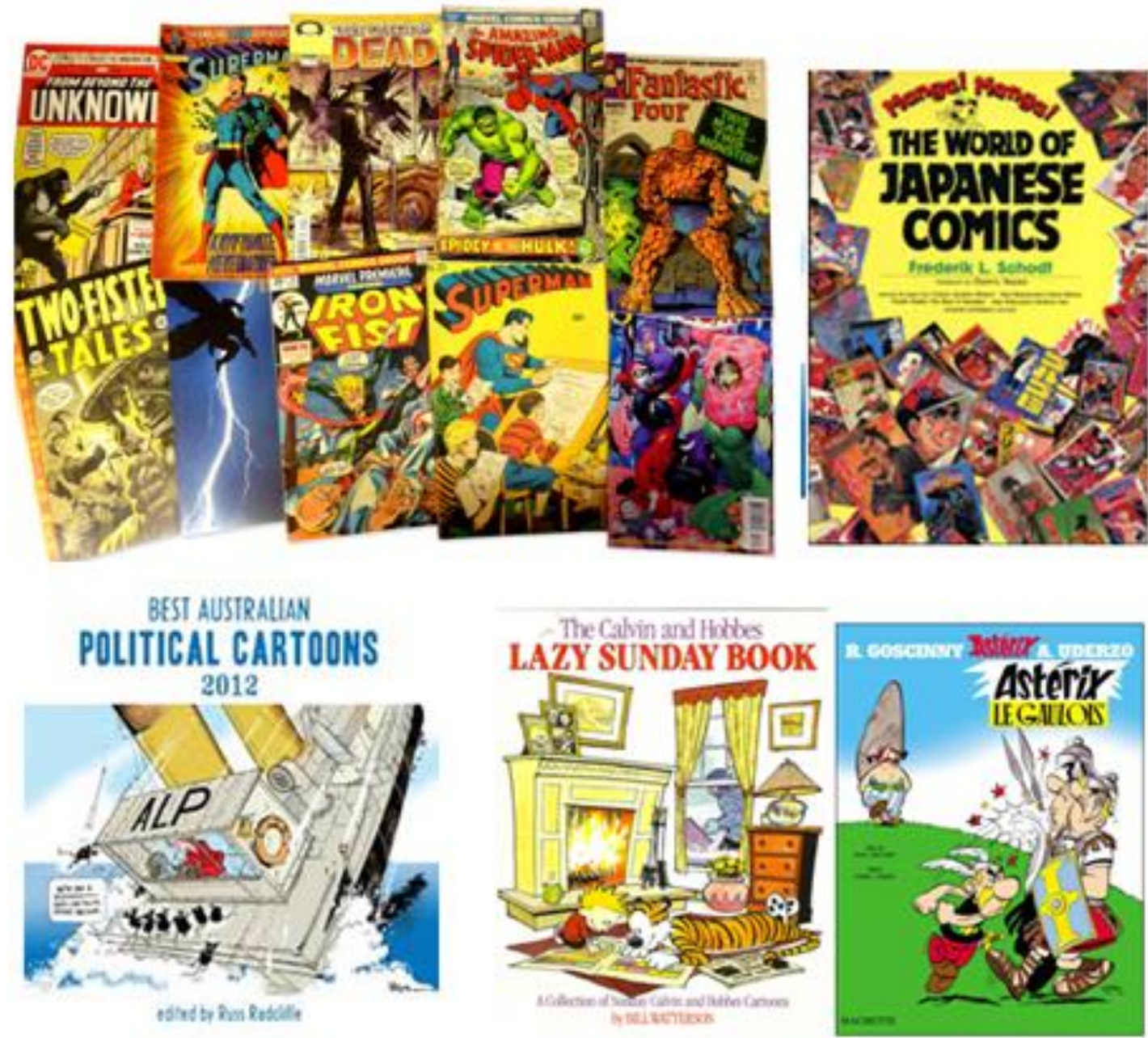

Figure 4: Examples of comics

Comics are based on the coexistence of texts and visual elements, namely pictures. "Often textual devices such as speech balloons, captions, and onomatopoeia indicate dialogue, narration, sound effects, or other information. Size and arrangement of panels contribute to narrative pacing." ${ }^{16}$ By using frames or panels they illustrate the story, facilitate comprehension, complete the meaning and make organic unit with it. It may occur that:

1. Text and pictures have got no sense without one another. And also that:

\footnotetext{
${ }^{14}$ Allison Sivak, "Across Time and Space: Reading Comics", 2003,

http://capping.slis.ualberta.ca/cap03/allison/othermedia.htm, last accessed 14. 01. 2015; Tamás Dunai, "Képregény Magyarországon" [Comics in Hungary], Médiakutató, Spring 2007, http://www.mediakutato.hu/cikk/2007 01 tavasz/02 kepregeny magyarorszagon, last accessed 14. 01. 2015. ${ }^{15}$ István Koós, “A képregény mint sajátos kifejezési forma” [Comics as a particular form of expression], Kalligram, vol. 13, Feb. 2004, http://www.kalligram.eu/Kalligram/Archivum/2004/XIII.-evf.-2004.-februar/Akepregeny-mint-sajatos-kifejezesi-forma, last accessed 14. 01. 2015.

${ }^{16}$ Wiki: Comics, http://en.wikipedia.org/wiki/Comics\#Comics studies, last accessed 14. 01. 2015.
} 
2. Text and pictures communicate different things to the reader at the same time. ${ }^{17}$

Here it is essential to mention that there are many types of comics according to cultures and languages. "Cartooning and similar forms of illustration are the most common imagemaking means in comics; fumetti is a form which uses photographic images. Common forms of comics include comic strips, editorial and gag cartoons, and comic books. Since the late 20th century, bound volumes such as graphic novels, comics albums, and tankōbon have become increasingly common, and online webcomics have proliferated in the 21st century." 18

Below a short list of comic types can be found. ${ }^{19}$

- Abstract Comics

- Caricature

- Crime Comics

- Editorial / Political Cartoons

- Graphic Novels

- Horror Comics

- Ligne clair ("clear line")

- Manga

- On-Line / Web Comics

- Political Cartoons

- Romance Comics

- Science Fiction Comics

- Super Heroes (Superheroes, Super Villains, Super)

- Tijuana Bibles / "Eight-Pagers"

- Underground / Alternative Comix

- War Comics

- Western Comics

- Wordless Comics / Mute Comics / Silent Comics

- 'Zines

Now I won't say more about the typology of comics, because it would lead us far from our central question. At this basic level it is enough that they share more or less the same characteristics as mentioned above.

\section{Comparison: comic reading vs. digital reading}

I shall now advert to another matter, namely the comparison between comic reading and digital reading. My aim is to find sufficient similarities among the characteristics of the two reading processes.

According to the literature we can say that comic reading is a fragmental, non-linear reading where even the linear plot is not cognizable in a linear way. It depends on the reader whether s/he looks at the visual elements or the text firstly, or what part of the visual elements $s /$ he starts with. According to the comic types the reader can decide on the

\footnotetext{
${ }^{17}$ Tamás Dunai, “Képregény Magyarországon” [Comics in Hungary], Médiakutató, Spring 2007, http://www.mediakutato.hu/cikk/2007 01 tavasz/02 kepregeny magyarorszagon, last accessed 14. 01.2015. ${ }^{18}$ Wiki: Comics, http://en.wikipedia.org/wiki/Comics\#Comics studies, last accessed 14. 01. 2015.

${ }^{19}$ ComicsResearch: http://www.comicsresearch.org/genres.html, last accessed 14. 01. 2015.
} 
direction of reading in spite of the fact that comics are narrative texts, and they usually intend to tell a story. But thanks to the special structure of comics, readers do not have to stick strictly to the story line during the reading process. The elements of a comic are open and freely walkable by the reader. ${ }^{20}$ This process is a kind of scanning where readers handle the complexity of text and pictures as a map for getting the relevant and interesting information which they need in order to understand the story. The cause behind this fact is that comic is a "hyperpicture", in other words: a web of pictures. This is especially true for the webcomics which we can read online with the help of a digital device. It is also true that comic is a "hybridpicture", a design product in which cohesion and coherence function in a special way. ${ }^{21}$

As we can see from these facts mentioned above, when we read a comic text, text reception needs an active user activity. Moreover, to understand and use the integration of pictures and text we need some sort of visual literacy. From this point of view it seems to me that reading comics and reading digital texts are similar processes. The importance of connecting pictures and texts can be similar in both cases. They give additional meaning and information one another, some kind of help for the sake of better understanding. Pictures and other visual elements have an essential function in guiding the reader's attention.

Why is this so important? Because reviewing the literature it can be seen that some researchers of digital reading are suspicious about the enormous amount of visual elements in digital texts. They think that the lots of illustration make the process of clear understanding difficult like a kind of digital noise. In the world of motion pictures and video games we get ready-made products, hence we don't have to use our cognitive processes as hard as when we read and think while being guided by our own fantasy. They say that too much visual effects lead us - particularly the children - back to picture reading which is a less effective, more superficial and already outdated way of reading, hence thinking. However that may be, in the case of comics the visual elements play an essential additional role in the reading process and they do not distract our attention but on the contrary: they help us in deep reading and complex understanding. If so then why couldn't the visual elements in a digital text work in the same way? If my hypothesis is true and the two reading processes (digital and comic) are similar then we can take a step forward in understanding our modern reading and cognitive mechanisms.

Even so, I think that I should examine this similarity in a critical way, too. So here are some possible objections:

- Comics are narrative texts; their aim is to tell a story, whereas digital texts have got numerous other functions and aims.

- Reading a story, getting informed and acquiring knowledge are not the same processes.

- There are too many types of digital texts and comics so it can be problematic, leastwise difficult to draw a strict parallel between them.

\footnotetext{
${ }^{20}$ E. J. Aarseth, "Nonlinearity and Literary Theory”, in Hyper/Text/Theory, ed by George Landow, Baltimore: Johns Hopkins University Press, 1994.

${ }^{21}$ Nóra Kovács, WebcoMix: Képregények az interneten [WebcoMix: Comics on the Internet] (2009), http://epa.oszk.hu/01500/01515/00006/pdf/mediarium-iii 3-4 07.pdf, last accessed 14. 01. 2015.
} 
However, nowadays comics are increasingly used for dissemination and for illustrating educational material. ${ }^{22}$ So they could have not only narrative, but also descriptive, explicative and informative functions. But I acknowledge that the similarities between the processes of comic reading and digital reading are questionable in some aspects, so I think that further research is required.

In Chart 1 I summarize some elements of comparison in.

\begin{tabular}{|c|c|c|}
\hline & DIGITAL READING PROCESS & COMIC READING PROCESS \\
\hline SIMILARITIES & \multicolumn{2}{|c|}{$\begin{array}{l}\text { fragmental, non-linear, scanning, the elements of a comic are open } \\
\text { and freely walkable by the reader, hypertext/picture, } \\
\text { hybridtext/picture, design product, special cohesion and } \\
\text { coherence, active user activity }\end{array}$} \\
\hline DIFFERENCES & $\begin{array}{l}\text { numerous text types, numerous } \\
\text { aims and intentions of the authors } \\
\text { for example: getting informed, } \\
\text { acquire knowledge etc. }\end{array}$ & $\begin{array}{l}\text { narrative texts, their aim is to } \\
\text { tell a story }\end{array}$ \\
\hline
\end{tabular}

Chart 1. Comparison: digital reading vs. comic reading

\section{Conclusion, a prognosis for possible further research}

In my paper I focused on digital reading literacy concerning the visual elements of comprehension. My main question was whether digital reading is similar to comic reading. I argued that reading digital texts including visual elements is a non-linear kind of reading which is actually very much like comic reading. First I gave some definitions for the fundamental expressions which I constantly used in my work. Secondly I drew up the main characteristics of digital reading in accordance with the latest literature. Then I gave a short summary about the specifics of comic reading and made a comparison between comic reading and digital reading focusing on their similarities.

As a conclusion I can say that having examined comic reading and digital reading, I should modify my hypothesis a little bit, which is now the following: reading digital texts including visual elements is a non-linear kind of reading which can be similar to reading comics.

What should be the next step? As a prognosis for possible further research I think that I should examine the different kinds of comics types and also the eye-tracking heat map researches which try to capture the tracks of our reading processes.

Concerning the future: what follows from the comic book-like reading literacy? On the one hand, this is another step of mapping the process of digital text reception processes. On the other hand, it can help in reconsidering the development of writing digital educational material. What is more, I hope that this research direction could find answers to my two fundamental questions which I posed in the beginning, namely:

- Do we read in a new kind of way, therefore we need new types of texts?

\footnotetext{
${ }^{22}$ Gyula Maksa, "Ismeretterjesztés és képregény" [Comics and disseminating information], Médiakutató, Spring 2007, http://www.mediakutato.hu/cikk/2007 01 tavasz/01 ismeretterjesztes es kepregeny, last accessed 14. 01.2015.
} 
- Do we have new types of texts; therefore we need to read in new kinds of ways?

At this point I firmly think that the answers for both questions are yes. It seems to me that reading processes and text types are closely related in a circular way: one follows from the other insofar as one defines the other. But in order to realize this connection we need to reconsider our ideas about literacy. Hereinafter I would like to do further researches on this topic.

\section{Acknowledgements}

Special thanks go to János Tanács PhD, Gábor Hamp PhD, István Danka PhD and all of the colleagues at the Department of Philosophy and History of Science, Budapest University of Technology and Economics, who helped me with their professional advice during my research.

\section{References}

[1] Wiki: Comics, http://en.wikipedia.org/wiki/Comics\#Comics_studies, last accessed 14. 01. 2015.

[2] Tamás Dunai, “Képregény Magyarországon” [Comics in Hungary], Médiakutató, Spring 2007, http://www.mediakutato.hu/cikk/2007_01_tavasz/02_kepregeny_magyarorszagon, last accessed 14. 01. 2015.

[3] Wiki: Comics, http://en.wikipedia.org/wiki/Comics\#Comics_studies, last accessed 14. 01. 2015.

[4] ComicsResearch: http://www.comicsresearch.org/genres.html, last accessed 14. 01. 2015.

[5] E. J. Aarseth, "Nonlinearity and Literary Theory", in Hyper/Text/Theory, ed by George Landow, Baltimore: Johns Hopkins University Press, 1994.

[6] Nóra Kovács, WebcoMix: Képregények az interneten [WebcoMix: Comics on the Internet] (2009), http://epa.oszk.hu/01500/01515/00006/pdf/mediarium-iii_3-4_07.pdf, last accessed 14. 01.2015.

[7] Gyula Maksa, "Ismeretterjesztés és képregény" [Comics and disseminating information], Médiakutató, Spring 2007,

http://www.mediakutato.hu/cikk/2007_01_tavasz/01_ismeretterjesztes_es_kepregeny, last accessed 14. 01. 2015. 